\title{
Technology Acceptance Model for Pervasive Computing: Mobile Business Intelligence Applications in Egypt ${ }^{1}$
}

\author{
Dr. Safaa A. Hussein²
}

\author{
Asmaa A. Abdelhamid ${ }^{3}$
}

\begin{abstract}
The Pervasive Computing is a new paradigm in information technology. Over the past two decades, many of Pervasive Computing and Internet of Things applications were developed to facilitate our life. The current study will mainly focus on pervasive computing applications at work settings and empirically validate the proposed model. The Mobile Business Intelligence application was chosen as an initial stage technology of pervasive computing. The study developed a proposed model which included the extended Unified Theory of Acceptance and Use of Technology (UTAUT) model along with the Trust and Perceived Convenience variables to investigate behavioral intention to use pervasive computing applications. Using Questionnaire survey, data was collected from 277 employees in some companies in Egypt. The correlation, regression and Structural Equation Modeling (SEM) were used for analysis. The results showed that effort expectancy explained 17.9\% of the variations in Perceived Convenience, 28.9\% of the variations in Performance Expectancy were justified by Perceived Convenience. The results also indicated that Performance Expectancy, Effort Expectancy, Social Influence, Facilitating Conditions, Perceived Convenience and Trust explained $46.7 \%$ of the variations in behavioral intention to use pervasive computing applications.
\end{abstract}

The paper will provide great benefits for entrepreneurs, policy makers, practitioners, researchers and educators though providing a clearer view and deep understanding for the issues related to different factors affecting the acceptance of pervasive computing applications such as Mobile Business Intelligence application at work settings in Egypt.

Keywords: Pervasive Computing - UTAUT - TAM - Trust - Mobile Business Intelligence Egypt

${ }^{1}$ Received in 19/10/2020, accepeted in 16/11/2020.

${ }^{2}$ Dr. Safaa Ahmed Hussein is currently Lecturer at Information Systems and Computers Deparment, Faculty of Commerce, Alexandria University (Safaa26bedo@yahoo.com)

${ }^{3}$ Asmaa Ahmed Abdelhamid is currently Assistant Teacher at Information Systems and Computers Deparment, Faculty of Commerce, Alexandria University (asmaahakeem2012@gmail.com) 


\section{1- Introduction}

Pervasive computing (PC) is a new paradigm in information technology (IT) that will change our lives and enrich human civilization by incorporating computers and humans and objects (Fano and Gershman, 2002, Kheiravar, 2018) Mark Weiser was the first author who used the term of Pervasive Computing in a paper published in 1991. More than 25 years ago, Mark Weiser expected that computers should take over the natural human environment. The PC applications are used anytime and anywhere. These applications may be used in education (Yahya et al., 2010), marketing (Kurkovsky and Harihar, 2006), banking (Hu et al., 2008), entertainment (Björk et al., 2002) , and health. This is a new trend in which computers will be implanted in our day to day movement and interact with our environment, both socially and physically. This will also help coordinate and regulate social interactions wherever and whenever these situations might happen (Lyytinen and Yoo, 2002).

The infrastructure for Pervasive Computing applications is costly; therefore, understanding long term usage and user acceptance of these applications is very important for determining if a pervasive computing application will justify its expensive, yet crucial, investment. However, applying any kind of technology acceptance model (TAM) on these applications would be very difficult due to the lack of the necessary and expensive infrastructure (Connelly, 2007, Riad et al, 2013, Abdullah and Ward, 2016, Binyamin, 2019). Thereby, the need to develop - a modified TAM model, to help identify the factors that aid users accept PC applications at work setting, using Mobile Business Intelligence (MBI) as an initial application of pervasive computing in work environment in Egypt - becomes vital. This study aims at achieving the following objectives:

- Illustrate pervasive computing environment and applications' characteristics.

- Develop a proposed modified acceptance model for pervasive computing applications in Egypt.

- Test the empirical validity of the proposed research model.

As mentioned earlier, Pervasive computing applications are widely spread in the majority of our daily activities, so the acceptance of pervasive applications are an essential factor in building or updating these applications. The acceptance of technology became an essential 
field of study for several decades. Despite widespread use of pervasive computing, yet there are few studies related to the acceptance of pervasive computing applications (Yoon \& Kim, 2007, Mohd and Sudin, 2011, Seuwou et al, 2017). Therefore, there is a big need to develop technology acceptance model for pervasive computing to predict user acceptance over time. Although few studies used UTUAT model as a base model in acceptance of pervasive computing, some important factors are still needs to be considered as well such as trust and convenience, which were shown to have a strong positive influence on behavioral intention to adopt a new technology (Koul, 2018). Thus the current research is trying to build a technology acceptance model based on UTAUT model, Trust and Convenience in work environment in order to answer the following research: What are factors affecting individuals' acceptance of pervasive computing applications?

The following section will discuss the literature in which several studies were found using the Technology Acceptance Model (TAM) as a theoretical basis for investigating the acceptance determinants of pervasive computing applications. However, the Unified Theory of Acceptance and Use of Technology (UTAUT) model was rarely used in the previous studies which investigated the acceptance of pervasive computing applications. Studies which developed and tested an acceptance model to pervasive computing were few. Therefore, this study attempted to fill this gap by developing and experimenting an acceptance model for pervasive computing based on UTAUT. Also two variables were added to the proposed model namely; Perceived Convenience and Trust in order to predict user acceptance of pervasive computing applications based on users' perception of Performance Expectancy (PE), Effort Expectancy, Social Influence (SI), Facilitating Conditions (FC), Perceived Convenience (PC) and Trust. As well as some moderating variables such as age, gender and work experience.

\section{2- Literature Review}

\section{2-1 Pervasive Computing}

Pervasive Computing (PC) is the flourishing trend of ingraining computational capability into mundane objects to make them effectively communicate and execute useful tasks in a way that decreases the end user's need to interact with computers as computers. In the two last decades, the pervasive computing converted from a futuristic version to a reality (Garfield, 2005). The researchers have attempted to solve everyday problems by using PC (Abowd and Mynatt, 2000). The main 
objective of PC is to provide "the right information to the right person at the right place at the right time". (Siewiorek, 2002). The rapid growth of PC has increased by the rapid advances in high technologies like wireless communications technologies, sensors for determining location, automatic identification technologies and flexible software architecture(Siewiorek, 2002).

PC enabled us to have access to real world information and to control everyday objects by embedding computing devices in them (Lee and Leem, 2005). Pervasive computing applications can be accessed by anyone, at any time, at anywhere and by any device (Lee and Leem, 2005). Kim and Chung (2014) concluded that context awareness and context information were important factors in maintaining security and confidentiality within companies, therefore PC can provide more effective customized services to users. The functionality of PC applications can be characterized by a set of attributes because it is used in many fields in our life. The integration of Cloud Computing and Internet of Things (Cloud and IOT) represents the next big leap ahead in the Future Internet. However, Cloud and IOT is faced by many challenges such as Security and Privacy, Heterogeneity, Reliability, Legal and social aspects, Big Data, Sensors Network and Monitoring.

\section{2-2 Unified Theory of Acceptance and Use of Technology (UTAUT)}

The Unified Theory of Acceptance and Use of Technology (UTAUT) has been broadened to be a universal model by (Venkatesh et al., 2003). The UTAUT model was built based on eight versions of technology acceptance models. These models and theories are the Theory of Reasoned Action (TRA), the Technology Acceptance Model (TAM), the Motivational Model (MM), the Theory of Planned Behavior (TPB), a model combining the Technology Acceptance Model and the Theory of Planned Behavior (C-TAM-TPB), the model of PC utilization, the Innovation Diffusion Theory (IDT), and the Social Cognitive Theory (SCT). The UTAUT model was established on four core determinants of intention and usage: Performance Expectancy (PE), Effort Expectancy (EE), Social Influence (SI) and Facilitating Conditions (FC), and up to four moderators of key relationships gender, age, experience and voluntariness of use (as shown in figure 1). 


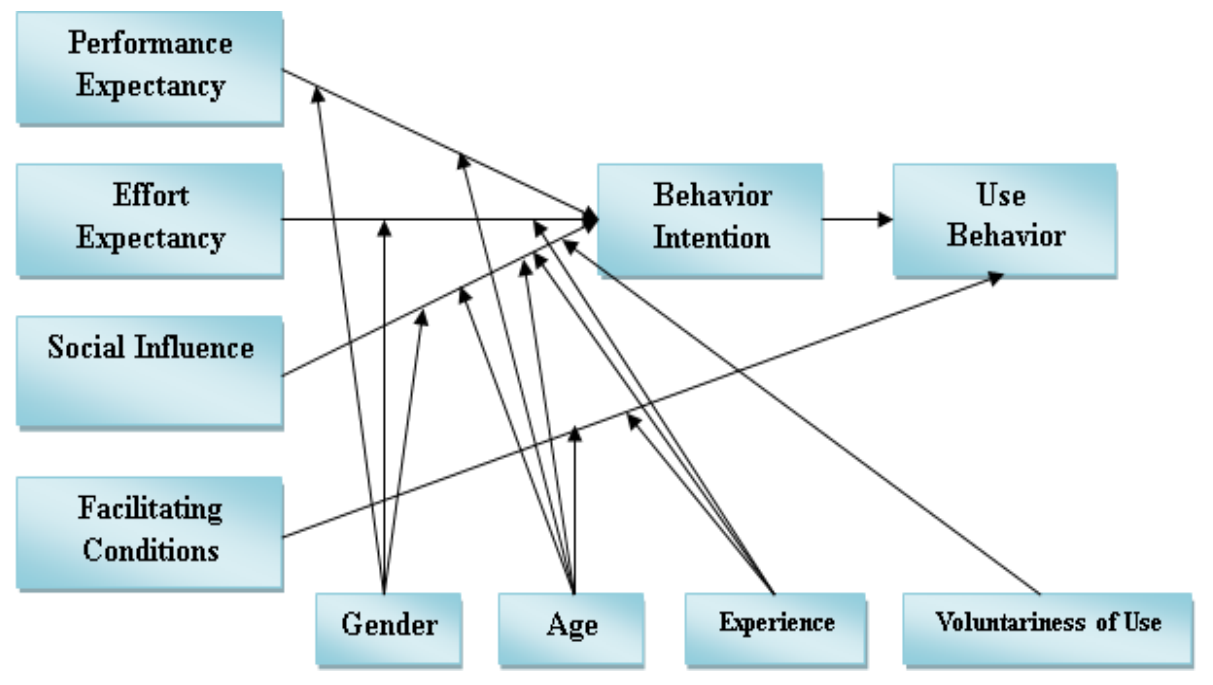

Figure 1: Unified Theory of Acceptance and Use of Technology

(Venkatesh et al., 2003)

The four core determinants of intention and usage constructs are:

- Performance Expectancy (PE) that is the degree to which one believes that utilizing the application will help him or her to obtain gains in job performance. Performance Expectancy matches five constructs from different models. These constructs are extrinsic motivation (MM), job-fit (MPCU), perceived usefulness (TAM/TAM2 and C-TAM-TPB), outcome expectations (SCT) and relative advantage (IDT). Age and Gender are expected to moderate the relationship between performance Expectancy and Intention to Use(Venkatesh et al., 2003).

- Effort Expectancy (EE) which is the degree of ease correlated to the use of the application. From current models, three constructs have been found to seize the concept of effort expectancy: complexity (MPCU), perceived ease of use (TAM/TAM2), and ease of use (IDT). Age, gender, and experience are expected to regulate the relation between effort expectance and behavioral intention to use (Venkatesh et al., 2003).

- Social influence (SI) that is the extent to which an individual observes that important people believe he / she ought to use the new application. Social influence matches subjective norm in TRA, TAM2, TPB/DTPB and C-TAM-TPB, social factors in MPCU, and image in IDT. 
Voluntariness of use, age, gender, and experience are expected to be regulating the relation between social influence and behavioral intention to use(Venkatesh et al., 2003).

- Facilitating conditions (FC) that is the extent to which a person sees that a technical and organizational infrastructure exists to support use of the application. It matches perceived behavioral control (TPB/DTPB, C-TAM-TPB), facilitating conditions (MPCU), and compatibility (IDT). Age and experience are expected to regulate the relation between use behavior and facilitating conditions (Venkatesh et al., 2003).

\section{2-3 The Proposed Research Model and Hypotheses}

UTAUT provided a powerful interpretation to user intention to use a technology and consequential usage behavior (Zhou et al., 2010). The choice of UTAUT is motivated by comprehension and power of explanation when it is compared with other technology acceptance models. The related technology acceptance models from literature that also serve our work will be used to build the proposed research model. The UTAUT model was modified by adding Perceived Convenience and Trust which reflect pervasive computing characteristic - see figure 2-.

The Performance Expectancy (PE) is the strongest predictor of behavioral intention. PE needs to be compatible with the new pervasive environment application. PE will be redefined as the exten to which a person believes that using a PC application (Mobile Business Intelligence) will help him / her to earn gains in job performance.

Perceived Usefulness as an alternative to PE was also considered as an important determinant of behavioral intension, (Davis, 1989, Connelly, 2007, Yoon and Kim, 2007, Chang et al., 2012, Bargshady et al., 2015 and Martínez-Torres et al., 2015) . Perceived Usefulness had a favorable significant impact on behavioral intention to use the wireless LAN (Yoon and Kim, 2007). Chang et al., 2012, also found in their study a positively continuance intention to use mobile technology for English learning. Additionally, PE played an essential role in the acceptance of 3G mobile telecommunication services (Wu et al., 2007). See appendix A for the items that were used to measure PE. Therefore, hypothesis $\mathrm{H} 1$ will be: 
H1: Performance Expectancy has a positive influence on behavioral intention to use Mobile Business Intelligence.

According to (Venkatesh et al., 2003), the Effort Expectancy (EE) is defined as the degree of comfort associated with the use of the system. Perceived Ease of Use (PEOU) matches EE in the UTAUT model. It is an important determinant to behavioral intention in TAM, TAM2 and TAM3. It is also significant at all points of measurement(Davis, 1989, Venkatesh \& Davis, 2000,Venkatesh \& Bala, 2008). Kassinen used TAM as a base to build his model for mobile services and called it the TAMMS (Kaasinen, 2005). In 2012, Brockmann et al used the TAMMS in Mobile Business Intelligence services. They considered PEOU as an important determinant to intension to use. (Garfield, 2005) used the UTAUT theory to have a better understanding of tablet Personal Computer (PC) in the corporate environment. The user of tablet $\mathrm{PC}$ will be closer to pervasive context and they considered EE an important factor in accepting the usage of tablet PC. In pervasive contexts, TAM was used as a theoretical model to measure the acceptance of wireless LAN by (Yoon and Kim, 2007) . They found that PEOU had a positive effect in determining behavioral intention in using wireless LAN. The study of MartínezTorres et al., 2015, showed that the connection between PEOU and behavioral intention was not grave for inexperienced groups, negating a few previous TAM studies that have found this relationship to be compelling. EE was measured by four items -see appendix A. Therefore, the second hypothesis will be:

H2: Effort Expectancy has a positive influence on behavioral intention to use Mobile Business Intelligence.

The TAM considered PU and PEOU as main determinants of attitude toward use and ignored Subjective Norm (SN), although it was a main construct in the Theory of Reasoned Action (TRA). In 2000, Davis and Venkatesh used TAM as the starting point to build TAM 2. They added Subjective Norm (SN) to TAM and found that SN had a significant positive impact on behavioral intension. Social Influence (SI) as an alternative to subjective norms was considered as a main determinant of Behavioral intention in UTAUT (Venkatesh et al., 2003, Connelly, 2007, Davis, 1989). SI is extent to which a person acknowledge that important people see that he or she should use the pervasive applications especially MBI. It 
was also found that the effect of SI on behavioral intention is far more compelling for older women, under mandatory conditions and limited experience (Venkatesh et al., 2003). Bargshady et al used the social effect which is created from co-workers, supervisors and friends as a direct determinant to user acceptance(Bargshady et al., 2015). SI was measured by four items- see appendix A. Therefore, the third hypothesis will be:

H3: Social Influence has a positive influence on behavioral intention to use Mobile Business Intelligence.

Venkatesh et al, 2003 added Facilitating Conditions (FC) as a main dereminant of system use. FC is known as the extent to which one sees that a technical and organizational infrastructure exists to further support use of the MBI. According to Venkatesh et al., 2003, when PE and EE were used, FC was insignificant in predicting behavioral intention. On the other hand, in 2012, Ghalandari investigated the effect of UTAUT' constructs on the acceptance of M-banking services in Iran. He found that Facilitating Conditions had a compelling positive effect on Behavioral intention to use M-banking services (Ghalandari, 2012). It was also found that Facilitating Conditions had a positive significant impact on behavioural intension to use $3 \mathrm{G}$ mobile telecommunication services $\mathrm{CWu}$ et al., 2007).The network connection, firewalls, security, and data comparison play an important role in facilitating the pervasive use of PC tablet (Garfield, 2005). However, recently the emerging topics of saving energy, internet speed and phone processing became important determinants of mobile applications usage acceptance. As a result, these items were added to the measurement of FC in this study. FC was measured by five items -see appendix A. Therefore, the fourth hypothesis will be:

H4: Facilitating Conditions have a positive influence on behavioral intention to use Mobile Business Intelligence.

"Convenience", as a construct, has not been operationalized and distinctly defined in the literature. The convenience construct could be viewed as a multidimensional construct (Brown, 1990). According to (Yoon and Kim, 2007), the perceived convenience has three dimensions in pervasive computing environment: time, place and execution. The Perceived Ease of Use (PEOU) was considered as a determinant to 
perceived convenience in wireless LAN environment (Yoon and Kim, 2007). In mobile learning, Chang et al also considered PEOU as a determinant of perceived convenience (Chang et al., 2012). Their study showed that PEOU had a positive influence on perceived convenience in using mobile phones for learning English. Effort Expectancy was also used as an alternative construct. Therefore, the fifth hypothesis was put as the following:

H5: Effort Expectancy has a positive influence on Perceived Convenience.

The perceived convenience mediates the relationship between PEOU and PU in pervasive computing environment. It is an important determinant to perceived usefulness (Yoon and Kim, 2007). Pervasive computing applications help users to achieve their jobs more efficiently and effectively, at any time and in any place. Yoo \& Kim considered that perceived convenience had a conclusive impact on PU for using wireless LAN. Chang et al, 2012 added perceived convenience as an external variable that affects PU and attitude to use. They concluded that perceived convenience positively affects PU and attitude to use. Therefore, the sixth hypothesis will be:

H6: Perceived Convenience has a positive influence on Performance Expectancy.

According to (Yoon and Kim, 2007), Perceived Convenience (PC) did not have a direct effect on pervasive computing acceptance. However, perceived convenience had an indirect impact on intension to accept wireless LAN through Perceived usefulness because PC was considered as a determinant of Perceived Usefulness. In 2012, Chang et al revealed that perceived usefulness, perceived ease of use and perceived convenience were important determinants of acceptance of English mobile learning. According to research, perceived convenience had a compelling effect on attitude toward the usage of the application which subsequently had a positive impact on intension to use the application. Perceived Convenience was measured by three items - see appendix A. Therefore, the Seventh hypothesis will be:

H7: Perceived Convenience has a positive influence on behavioral intention to use Mobile Business Intelligence. 
In 2008, Min \& Qu used the UTAUT as a starting point to build an acceptance model for Mobile-Commerce in China. They added trust as an important determinant of Mobile-Commerce acceptance. In 2017, Septiani et al analyzed technology acceptance theories to determine the successful factors of online transportation in Indonesia. They considered trust as an important determinant in E-commerce because it is related to personal information, money and location. Alharbi, 2017, used the UTAUT model with the addition of trust construct to investigate the impact of trust on users' behavioral intention to use cloud computing. According to results, trust had a major effect on behavioral intention to use cloud computing. Trust was measured by three items - see appendix A. Therefore, the eighth hypothesis will be:

H8: Trust has a positive Influence on behavioral intention to use Mobile Business Intelligence.

Voluntariness, age, gender, and exerience were proposed as moderator's variables in UTAUT model (Venkatesh et al., 2003). However, voluntariness was not be included in this paper as all the mobile business intelligence tools which were used by the participants in the study were applied in a mandatory work setting.

Age was used as moderator between Behavioral Intension and Performance Expectancy, Social Influence, and Effort Expectancy. (Venkatesh et al, 2003, Maruping et al., 2017, Al-Gahtani et al., 2007 and Ghalandari, 2012). Age was also a moderator variable in PTAM between intension to use and Perceived Usefulness, Perceived Ease of use, Social Influence, trust, integration (Connelly, 2007). Therefore, this paper added age as a moderator between Facilitating Conditions and Behavioral Intension to use pervasive computing. Thus, the ninth hypothesis was divided into three sub-hypotheses as follows:

H9 A: Age is moderating the relationship between Performance Expectancy and behavioral intention.

H9B: Age is moderating the relationship between Effort Expectancy and behavioral intention.

H9C: Age is moderating the relationship between Social Influence and behavioral intention. 
Gender was used as moderator between Behavioral Intension and Performance Expectancy, Effort Expectancy and Social Influence. (Venkatesh et al, 2003, Maruping et al., 2017), (Al-Gahtani et al., 2007 and Ghalandari, 2012). Gender was also a moderator variable in PTAM between intension to use and Perceived Usefulness, integration, Perceived Ease of use, and Social Influence, trust (Connelly, 2007). Therefore, the tenth hypothesis was divided into three sub-hypotheses as follows:

H10 A: Gender is moderating the relationship between Performance Expectancy and behavioral intention.

H10 B: Gender is moderating the relationship between Effort Expectancy and behavioral intention.

H10 C: Gender is moderating the relationship between Social Influence and behavioral intention.

Experience was used as moderator between Effort Expectancy and Social Influence. (Venkatesh et al, 2003, Maruping et al., 2017, Al-Gahtani et al., 2007 and Ghalandari, 2012). Therefore, the eleventh hypothesis was divided into two sub-hypotheses as follows:

H11 A: Experience is moderating the relationship between Effort Expectancy and behavioral intention.

H11 B: Experience is moderating the relationship between Social Influence and behavioral intention.

Therefore, based on the previous hypotheses, figure 2 represents the proposed research model for this study 


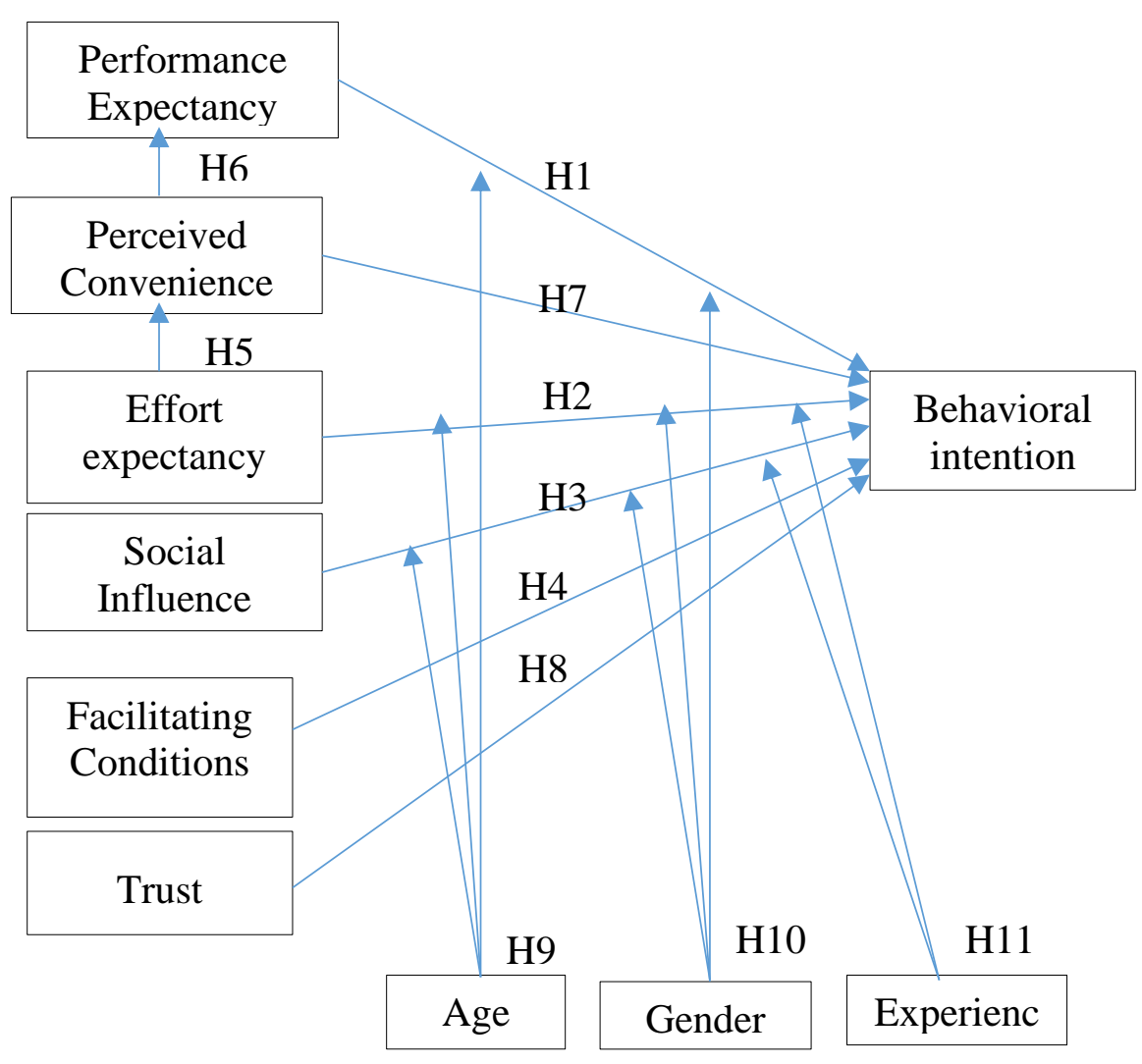

Figure 2: The proposed Research Model

\section{3- Research Methodology}

The paper reviewed the published literature related to Technology Acceptance Model (TAM) as a theoretical basis for investigating the acceptance determinants of pervasive computing applications. According to this review, the paper confirmed a suggested conceptual model using a quantitative approach and positivist research philosophy. Where quantitative data are collected according to survey strategy through questionnaires to assess different measures of the study.

In this paper, a survey questionnaire approach was used to collect data about constructs affecting the use of pervasive computing specially MBI (see appendix A). The questionnaire had 26 statements that aimed to test research hypotheses. This study depended on Cross-Sectional research because the questionnaire was answered once by respondents. 
The population of this study was employees that were working in companies that utilize Mobile Business Intelligence in Egypt. Nonprobability sampling was used for data gathering. There was a difficulty in identifying companies that use Mobile Business Intelligence applications in Egypt. Therefore, the convenience sample was used on as a type of non-probabilistic sample. Companies that were selected were Unilever, Pepsi, Coca-Cola, Mansour Group, Sekalam, Faragalla group and Pharco. In total, 265 respondents were gathered, and 227 usable questionnaires were used for analysis.

This questionnaire was established online by using Google forms. Out of 280 questionnaires, 150 of them were sent to employees over E-mail and Facebook. 135 respondents filled out and submitted this questionnaire with $90 \%$ response rate. The remaining 130 copies of the questionnaires were printed and distributed to employees at Coca-Cola and Sekalam companies. 38 copies of the questionnaire were excluded because they were not completed. In total 227 questionnaires were eligible for analysis.

Table 1 shows the respondent profile. It was observed that the percentage of Female is higher than Male with 53.3\%. Further, Age from 23 to 35 years is the highest in the research sample with 59.5\%; also, the Government Sector is the highest percentage of responses with percentage of $32.2 \%$. Finally, the percentage of yes answer of the question "Do you have experience in using MBI applications"? is higher than no answer with $72.2 \%$ of responses.

Table 1: Respondent profile

\begin{tabular}{|c|c|c|c|}
\hline & Frequency & Percent & Total \\
\hline \multicolumn{4}{|l|}{ Gender } \\
\hline Male & 106 & 46.7 & \multirow{2}{*}{227} \\
\hline Female & 121 & 53.3 & \\
\hline \multicolumn{4}{|l|}{ Age } \\
\hline 23 to 35 & 135 & 59.5 & \multirow{3}{*}{227} \\
\hline 36 to 45 & 71 & 31.3 & \\
\hline 46 to 60 & 21 & 9.3 & \\
\hline \multicolumn{3}{|l|}{ Sector } & \multirow{5}{*}{227} \\
\hline Government Sector & 73 & 32.2 & \\
\hline Banking Sector & 14 & 6.2 & \\
\hline Industrial Sector & 30 & 13.2 & \\
\hline Service Sector & 46 & 20.3 & \\
\hline
\end{tabular}




\begin{tabular}{|l|c|c|c|}
\hline Private Sector & 64 & 28.2 & \\
\cline { 1 - 3 } Experience & 164 & 72.2 & \multirow{2}{*}{227} \\
\cline { 1 - 3 } Yes & 63 & 27.8 & \\
\hline No & & &
\end{tabular}

Table 2 shows the frequency tables for the research variables. It was noted that responses range between strongly disagree and strongly agree, meaning that not all responses are in the zone of agreement. In other words, the sample under study faces an issue as the respondents' answers were not all in the agreement zone. Testing of hypothesis will be observed in order to identify which variables direct customers to be in the disagreement zone.

Table 2: Descriptive Analysis for the Research Variables

\begin{tabular}{|l|c|c|c|c|c|}
\hline & \multicolumn{5}{|c|}{ Frequency } \\
\cline { 2 - 6 } & $\mathbf{1}$ & $\mathbf{2}$ & $\mathbf{3}$ & $\mathbf{4}$ & $\mathbf{5}$ \\
\hline Performance Expectancy & 5 & 7 & 35 & 104 & 76 \\
\hline Effort Expectancy & 0 & 8 & 30 & 89 & 100 \\
\hline Social Influence & 0 & 7 & 62 & 106 & 52 \\
\hline Facilitating Conditions & 0 & 12 & 42 & 106 & 67 \\
\hline Perceived Convenience & 0 & 15 & 42 & 79 & 91 \\
\hline Trust & 3 & 8 & 34 & 93 & 89 \\
\hline Behavioral intention & 10 & 15 & 54 & 80 & 68 \\
\hline
\end{tabular}

\section{4- Results}

A pilot study was conducted to be sure the questionnaire statements are phrased in a well format. It was conducted by 30 Respondents. Validity is measured by the two main factors. First, the Average Variance Extracted (AVE); it represents the average community for each latent factor. The (AVE) result should be greater than 0.5 to imply adequate validity. Second is the factor loading for each item (statement) which should be greater than or equal to 0.4 (Hair Jr, Hult, Ringle, \& Sarstedt, 2016).

To examine reliability, each factor is measured using a group of statements, indicates how consistently the instrument taps the variable which can be examined by Cronbach's Alpha, the most common used test of reliability. The range of Alpha coefficient comes between 0 and 1, the higher the score the higher the reliability. If Alpha coefficients are greater than or equal to 0.7 , it implies adequate reliability (Tavakol \& Dennick, 2011). 
The following section displays the results from the full sample of 227 respondents. Table 3 shows the results of validity and reliability of the pilot study.

Table 3: Validity and Reliability Tests for the whole sample

\begin{tabular}{|c|c|c|c|c|c|}
\hline Variables & KMO & AVE & $\begin{array}{c}\text { Cronbach's } \\
\text { Alpha } \\
\end{array}$ & Items & $\begin{array}{c}\text { Factor } \\
\text { Loading }\end{array}$ \\
\hline \multirow{4}{*}{$\begin{array}{l}\text { Performance } \\
\text { Expectancy }\end{array}$} & \multirow{4}{*}{.775} & \multirow{4}{*}{$68.868 \%$} & \multirow{4}{*}{.831} & Items1 & .772 \\
\hline & & & & Items 2 & .756 \\
\hline & & & & Items3 & .783 \\
\hline & & & & Items 4 & .443 \\
\hline \multirow{4}{*}{ Effort Expectancy } & \multirow{4}{*}{.765} & \multirow{4}{*}{$66.979 \%$} & \multirow{4}{*}{.826} & Items 1 & .439 \\
\hline & & & & Items 2 & .808 \\
\hline & & & & Items3 & .804 \\
\hline & & & & Items 4 & .629 \\
\hline \multirow{4}{*}{ Social Influence } & \multirow{4}{*}{.722} & \multirow{4}{*}{$53.416 \%$} & \multirow{4}{*}{.708} & Items1 & .523 \\
\hline & & & & Items 2 & .655 \\
\hline & & & & Items3 & .554 \\
\hline & & & & Items 4 & .404 \\
\hline \multirow{5}{*}{$\begin{array}{l}\text { Facilitating } \\
\text { Conditions }\end{array}$} & \multirow{5}{*}{.705} & \multirow{5}{*}{$53.803 \%$} & \multirow{5}{*}{.783} & Items1 & .537 \\
\hline & & & & Items 2 & .544 \\
\hline & & & & Items3 & .486 \\
\hline & & & & Items 4 & .652 \\
\hline & & & & Items5 & .471 \\
\hline \multirow{3}{*}{$\begin{array}{l}\text { Perceived } \\
\text { Convenience }\end{array}$} & \multirow{3}{*}{.708} & \multirow{3}{*}{$73.467 \%$} & \multirow{3}{*}{.819} & Items1 & .748 \\
\hline & & & & Items2 & .682 \\
\hline & & & & Items3 & .774 \\
\hline Trust & .643 & $67.552 \%$ & .754 & Items1 & .606 \\
\hline
\end{tabular}




\begin{tabular}{|c|c|c|c|c|c|}
\hline Variables & KMO & AVE & $\begin{array}{c}\text { Cronbach's } \\
\text { Alpha }\end{array}$ & Items & $\begin{array}{c}\text { Factor } \\
\text { Loading }\end{array}$ \\
\hline & & & & Items2 & .782 \\
\hline & & & & Items3 & .639 \\
\hline \multirow{3}{*}{ Behavioral intention } & \multirow{3}{*}{.698} & \multirow{3}{*}{$85.306 \%$} & \multirow{3}{*}{.912} & Items1 & .744 \\
\hline & & & & Items2 & .901 \\
\hline & & & & Items3 & .914 \\
\hline
\end{tabular}

\section{4-1 Structural Equation Modeling for the Effect of the Research Variables}

The hypotheses of this study were tested using the correlation, regression and SEM modeling. Table 4 shows the correlation matrix for the relationship between Performance Expectancy, Effort Expectancy, Social Influence, Facilitating Conditions, Perceived Convenience, Trust and Behavioral Intension. It was found that the relationship is significant, as the corresponding P-value is less than 0.05 and correlation coefficients are $0.455,0.304,0.509,0.366,0.512$ and 0.469 respectively.

Table 4: Correlation Matrix between Research Variables and Behavioral Intention

\begin{tabular}{|c|c|c|c|c|c|c|c|c|c|}
\hline \multicolumn{10}{|c|}{ Correlations } \\
\hline & & & 1 & 2 & 3 & 4 & 5 & 6 & 7 \\
\hline \multirow{12}{*}{ 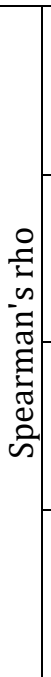 } & \multirow{3}{*}{ Performance Expectancy } & $\begin{array}{l}\text { Correlation } \\
\text { Coefficient }\end{array}$ & 1.000 & & & & & & \\
\hline & & P-Value & & & & & & & \\
\hline & & $\mathrm{N}$ & 227 & & & & & & \\
\hline & \multirow{3}{*}{ Effort Expectancy } & $\begin{array}{l}\text { Correlation } \\
\text { Coefficient }\end{array}$ & $472^{* *}$ & 1.000 & & & & & \\
\hline & & P-Value & .000 & . & & & & & \\
\hline & & $\mathrm{N}$ & 227 & 227 & & & & & \\
\hline & \multirow{3}{*}{ Social Influence } & $\begin{array}{l}\text { Correlation } \\
\text { Coefficient }\end{array}$ & $392^{* *}$ & $337^{* *}$ & * 1.000 & & & & \\
\hline & & P-Value & .000 & .000 & . & & & & \\
\hline & & $\mathrm{N}$ & 227 & 227 & 227 & & & & \\
\hline & \multirow{3}{*}{ Facilitating Conditions } & $\begin{array}{l}\text { Correlation } \\
\text { Coefficient }\end{array}$ & $332^{* *}$ & $442^{* *}$ & $* 298^{* *}$ & 1.000 & & & \\
\hline & & P-Value & .000 & .000 & .000 & & & & \\
\hline & & $\mathrm{N}$ & 227 & 227 & 227 & 227 & & & \\
\hline
\end{tabular}




\begin{tabular}{|c|c|c|c|c|c|c|c|c|}
\hline \multirow{3}{*}{ Perceived Convenience } & $\begin{array}{l}\text { Correlation } \\
\text { Coefficient }\end{array}$ & $466^{* *}$ & $.395^{* *}$ & $.379^{* *}$ & $491^{* *}$ & 1.000 & & \\
\hline & P-Value & .000 & .000 & .000 & .000 & . & & \\
\hline & $\mathrm{N}$ & 227 & 227 & 227 & 227 & 227 & & \\
\hline \multirow{3}{*}{ Trust } & $\begin{array}{l}\text { Correlation } \\
\text { Coefficient }\end{array}$ & $.504^{* *}$ & $459^{* *}$ & $.322^{* *}$ & $362^{* *}$ & $343^{* *}$ & 1.000 & \\
\hline & P-Value & .000 & .000 & .000 & .000 & .000 & . & \\
\hline & $\mathrm{N}$ & 227 & 227 & 227 & 227 & 227 & 227 & \\
\hline \multirow{3}{*}{ Behavioral Intension } & $\begin{array}{l}\text { Correlation } \\
\text { Coefficient } \\
\end{array}$ & $455^{* *}$ & $.304^{* *}$ & $.509^{* *}$ & $366^{* *}$ & $.512^{* *}$ & $469^{* *}$ & 1.000 \\
\hline & P-value & .000 & .000 & .000 & .000 & .000 & .000 & . \\
\hline & $\mathrm{N}$ & 227 & 227 & 227 & 227 & 227 & 227 & 227 \\
\hline
\end{tabular}

The regression models of the research variables effect are conducted on Behavioral Intension. Table 5 shows the regression model fitted for the effect of Research Variables and Behavioral Intention. A compelling positive effect of Social Influence, Perceived Convenience and Trust on Behavioral Intension has been noted, as the regression coefficients are $0.371,0.276$ and 0.337 and P-values are 0.000. However, there is an insignificant effect of Performance Expectancy, Effort Expectancy and Facilitating Conditions on Behavioral Intension as the regression coefficients are $0.068,-0.136$ and 0.151 and P-values are more than 0.05 . Moreover, the R square is 0.427 which means $42.7 \%$ of the variation of the Behavioral Intention can be explained by the independent variables together.

Table5: Regression Model of Research Variables and Behavioral Intention

\begin{tabular}{|c|c|c|c|c|c|c|}
\hline \multirow[t]{2}{*}{ Model } & \multicolumn{2}{|c|}{$\begin{array}{l}\text { Unstandardized } \\
\text { Coefficients }\end{array}$} & \multirow{2}{*}{\begin{tabular}{|c|c|}
$\begin{array}{c}\text { Standardized } \\
\text { Coefficients }\end{array}$ \\
$\mathbf{r}$ & Beta \\
\end{tabular}} & \multirow[t]{2}{*}{$\mathbf{t}$} & \multirow{2}{*}{$\begin{array}{c}\text { P- } \\
\text { Value }\end{array}$} & \multirow{2}{*}{$\begin{array}{c}\text { R- } \\
\text { Square }\end{array}$} \\
\hline & B & Std. Error & & & & \\
\hline (Constant) & -.470 & .373 & & -1.261 & .209 & \multirow{7}{*}{.427} \\
\hline Performance Expectancy & .068 & .085 & .057 & .802 & .424 & \\
\hline Effort Expectancy & -.136 & .087 & -.103 & -1.567 & .119 & \\
\hline Social Influence & .371 & .081 & .270 & 4.599 & .000 & \\
\hline Facilitating Conditions & .151 & .082 & .117 & 1.857 & .065 & \\
\hline Perceived Convenience & .276 & .078 & .235 & 3.544 & .000 & \\
\hline Trust & .337 & .080 & .277 & 4.217 & .000 & \\
\hline
\end{tabular}

\section{4-2 Testing the Moderating Variables:}

In this section the relationship between moderating variables (Gender, Age, Experience) research variables (Performance Expectancy, Effort 
Expectancy, Social Influence, Facilitating Conditions, Perceived Convenience and Trust) were tested.

Table 6 shows the regression model fitted for the moderation role of Age between Performance Expectancy and Behavioral Intension. It was found that there is an insignificant moderation of Age between Performance Expectancy and Behavioral Intension as P-value is more than 0.05 .

Table 6: Age moderation between Performance Expectancy and Behavioral Intension

\begin{tabular}{|l|c|c|c|c|c|}
\hline \multirow{2}{*}{ Model } & \multicolumn{2}{|c|}{$\begin{array}{c}\text { Unstandardized } \\
\text { Coefficients }\end{array}$} & $\begin{array}{c}\text { Standardized } \\
\text { Coefficients }\end{array}$ & \multirow{2}{*}{ t } & \multirow{2}{*}{ P-Value } \\
\cline { 2 - 4 } & B & Std. Error & Beta & & \\
\hline (Constant) & 1.051 & .717 & & 1.466 & .144 \\
\hline Age & .398 & .438 & .244 & .910 & .364 \\
\hline Performance Expectancy & .633 & .175 & .529 & 3.616 & .000 \\
\hline PE_Age & -.068 & .107 & -.192 & -.640 & .523 \\
\hline \multicolumn{7}{|l|}{ a. Dependent Variable: Behavioral Intension } \\
\hline
\end{tabular}

Table 7 shows the regression model fitted for the moderation role of Age between Effort Expectancy and Behavioral Intension. It was found that there is an insignificant moderation of Age between Effort Expectancy and Behavioral Intension as P-value is more than 0.05.

Table 7: Age moderation between Effort Expectancy and Behavioral Intension

\begin{tabular}{|l|c|c|c|c|c|}
\hline \multirow{2}{*}{ Model } & \multicolumn{2}{|c|}{$\begin{array}{c}\text { Unstandardized } \\
\text { Coefficients }\end{array}$} & $\begin{array}{c}\text { Standardized } \\
\text { Coefficients }\end{array}$ & \multirow{2}{*}{ t } & \multirow{2}{*}{ P-Value } \\
\cline { 2 - 5 } & B & Std. Error & Beta & & \\
\hline (Constant) & .908 & .877 & & 1.036 & .301 \\
\hline Age & .703 & .528 & .431 & 1.333 & .184 \\
\hline Effort Expectancy & .616 & .203 & .464 & 3.034 & .003 \\
\hline EE_Age & -.123 & .125 & -.334 & -.989 & .324 \\
\hline a. Dependent Variable: Behavioral Intension \\
\hline
\end{tabular}

Table 8 shows the regression model fitted for the moderation role of Age between Social Influence and Behavioral Intension. It was found that there is an insignificant moderation of Age between Social Influence and Behavioral Intension as P-value is more than 0.05. 
Table 8: Age moderation between Social Influence and Behavioral Intension

\begin{tabular}{|l|c|c|c|c|c|}
\hline \multirow{2}{*}{ Model } & \multicolumn{2}{|c|}{$\begin{array}{c}\text { Unstandardized } \\
\text { Coefficients }\end{array}$} & $\begin{array}{c}\text { Standardized } \\
\text { Coefficients }\end{array}$ & \multirow{2}{*}{ t } & \multirow{2}{*}{ P-Value } \\
\cline { 2 - 5 } & B & Std. Error & Beta & & \\
\hline (Constant) & .706 & .818 & & .863 & .389 \\
\hline Age & .334 & .510 & .205 & .655 & .513 \\
\hline Social Influence & .748 & .205 & .545 & 3.652 & .000 \\
\hline SI_Age & -.055 & .127 & -.149 & -.433 & .666 \\
\hline
\end{tabular}

Table 9 shows the regression model fitted for the moderation role of Gender between Performance Expectancy and Behavioral Intension. It was found that there is an insignificant moderation of Gender between Performance Expectancy and Behavioral Intension as P-value is more than 0.05 .

Table 9: Gender moderation between Performance Expectancy and Behavioral Intension

\begin{tabular}{|l|c|c|c|c|c|}
\hline \multirow{2}{*}{ Model } & \multicolumn{2}{|c|}{$\begin{array}{c}\text { Unstandardized } \\
\text { Coefficients }\end{array}$} & $\begin{array}{c}\text { Standardized } \\
\text { Coefficients }\end{array}$ & \multirow{2}{*}{ t } & \multirow{2}{*}{ P-Value } \\
\cline { 2 - 5 } & B & Std. Error & Beta & & \\
\hline (Constant) & 1.533 & .927 & & 1.653 & .100 \\
\hline Gender & .079 & .596 & .037 & .133 & .894 \\
\hline Performance Expectancy & .604 & .223 & .505 & 2.708 & .007 \\
\hline PE_Gender & -.049 & .144 & -.113 & -.344 & .732 \\
\hline \multicolumn{7}{|l|}{ a. Dependent Variable: Behavioral Intension } \\
\hline
\end{tabular}

Table 10 shows the regression model fitted for the moderation role of Gender between Effort Expectancy and Behavioral Intension. It was found that there is an insignificant moderation of Gender between Effort Expectancy and Behavioral Intension as P-value is more than 0.05.

Table 10: Gender moderation between Effort Expectancy and Behavioral Intension

\begin{tabular}{|l|c|c|c|c|c|}
\hline \multirow{2}{*}{ Model } & \multicolumn{2}{|c|}{$\begin{array}{c}\text { Unstandardized } \\
\text { Coefficients }\end{array}$} & $\begin{array}{c}\text { Standardized } \\
\text { Coefficients }\end{array}$ & \multirow{2}{*}{ t } & \multirow{2}{*}{ P-Value } \\
\cline { 2 - 4 } & B & Std. Error & Beta & & \\
\hline (Constant) & .811 & 1.152 & & .704 & .482 \\
\hline Gender & .817 & .725 & .379 & 1.128 & .261 \\
\hline Effort Expectancy & .744 & .267 & .561 & 2.791 & .006 \\
\hline EE_Gender & -.219 & .168 & -.501 & -1.301 & .195 \\
\hline a. Dependent Variable: Behavioral Intension \\
\hline
\end{tabular}


Table 11 shows the regression model fitted for the moderation role of Gender between Social Influence and Behavioral Intension. It was found that there is an insignificant moderation of Gender between Social Influence and Behavioral Intension as P-value is more than 0.05.

Table 11: Gender moderation between Social Influence and Behavioral Intension

\begin{tabular}{|l|c|c|c|c|c|}
\hline \multirow{2}{*}{ Model } & \multicolumn{2}{|c|}{$\begin{array}{c}\text { Unstandardized } \\
\text { Coefficients }\end{array}$} & $\begin{array}{c}\text { Standardized } \\
\text { Coefficients }\end{array}$ & \multirow{2}{*}{ t } & \multirow{2}{*}{ P-Value } \\
\cline { 2 - 4 } & B & Std. Error & Beta & & \\
\hline (Constant) & .988 & 1.017 & & .971 & .333 \\
\hline Gender & .145 & .639 & .067 & .227 & .821 \\
\hline Social Influence & .742 & .254 & .541 & 2.922 & .004 \\
\hline SI_Gender & -.051 & .161 & -.106 & -.317 & .752 \\
\hline
\end{tabular}

Table 12 shows the regression model fitted for the moderation role of Experience between Effort Expectancy and Behavioral Intension. It was found that there is an insignificant moderation of Experience between Effort Expectancy and Behavioral Intension as P-value is more than 0.05.

Table 12: Experience moderation between Effort Expectancy and Behavioral Intension

\begin{tabular}{|l|c|c|c|c|c|}
\hline \multirow{2}{*}{\multicolumn{1}{|c|}{ Model }} & \multicolumn{2}{|c|}{$\begin{array}{c}\text { Unstandardized } \\
\text { Coefficients }\end{array}$} & $\begin{array}{c}\text { Standardized } \\
\text { Coefficients }\end{array}$ & \multirow{2}{*}{ t } & \multirow{2}{*}{ P-Value } \\
\cline { 2 - 4 } & B & Std. Error & Beta & & \\
\hline (Constant) & 2.268 & .423 & & 5.361 & .000 \\
\hline Gender & -.097 & .137 & -.045 & -.711 & .478 \\
\hline Effort Expectancy & .453 & .090 & .341 & 5.046 & .000 \\
\hline EE_Experience & -.045 & .037 & -.082 & -1.207 & .229 \\
\hline \multicolumn{7}{|l|}{ a. Dependent Variable: Behavioral Intension } \\
\hline
\end{tabular}

Table 13 shows the regression model fitted for the moderation role of Experience between Social Influence and Behavioral Intension. It was found that there is an insignificant moderation of Experience between Social Influence and Behavioral Intension as P-value is more than 0.05. 
Table 13: Experience moderation between Social Influence and Behavioral Intension

\begin{tabular}{|l|c|c|c|c|c|}
\hline \multirow{2}{*}{ Model } & \multicolumn{2}{|c|}{$\begin{array}{c}\text { Unstandardized } \\
\text { Coefficients }\end{array}$} & $\begin{array}{c}\text { Standardized } \\
\text { Coefficients }\end{array}$ & \multirow{2}{*}{ t } & \multirow{2}{*}{ P-Value } \\
\cline { 2 - 5 } & B & Std. Error & Beta & & \\
\hline (Constant) & 1.316 & .383 & & 3.437 & .001 \\
\hline Gender & -.046 & .126 & -.021 & -.366 & .715 \\
\hline Social Influence & .705 & .088 & .514 & 8.001 & .000 \\
\hline SI_Experience & -.039 & .037 & -.069 & -1.073 & .284 \\
\hline \multicolumn{7}{|l|}{ a. Dependent Variable: Behavioral Intension } \\
\hline
\end{tabular}

Therefore Table 14 represents a summary of research hypotheses analysis

\begin{tabular}{|c|l|c|}
\hline Hypothesis & \multicolumn{1}{|c|}{ Description } & Results \\
\hline $\mathrm{H}_{1}$ & $\begin{array}{l}\text { There is a significant relation between } \\
\text { Performance Expectancy and BI }\end{array}$ & Fully Supported \\
\hline $\mathrm{H}_{2}$ & $\begin{array}{l}\text { There is a significant relation between Effort } \\
\text { Expectancy and BI }\end{array}$ & Fully Supported \\
\hline $\mathrm{H}_{3}$ & $\begin{array}{l}\text { There is a significant relation between Social } \\
\text { Influence and BI }\end{array}$ & Fully Supported \\
\hline $\mathrm{H}_{4}$ & $\begin{array}{l}\text { There is a significant relation between } \\
\text { Facilitating Conditions and BI }\end{array}$ & Fully Supported \\
\hline $\mathrm{H}_{5}$ & $\begin{array}{l}\text { There is a significant relation between } \\
\text { Perceived Convenience and Effort Expectancy }\end{array}$ & Fully Supported \\
\hline $\mathrm{H}_{6}$ & $\begin{array}{l}\text { There is a significant relation between } \\
\text { Perceived Convenience and Performance } \\
\text { Expectancy }\end{array}$ & Fully Supported \\
\hline $\mathrm{H}_{7}$ & $\begin{array}{l}\text { There is a significant relation between } \\
\text { Perceived Convenience and BI }\end{array}$ & Fully Supported \\
\hline $\mathrm{H}_{8}$ & $\begin{array}{l}\text { There is a significant relation between Trust } \\
\text { and BI }\end{array}$ & Fully Supported \\
\hline $\mathrm{H}_{9}$ & $\begin{array}{l}\text { Age moderate the relationship between the } \\
\text { independent variables (Performance } \\
\text { Expectancy, Effort Expectancy, Social } \\
\text { Influence, Facilitating Conditions) and BI }\end{array}$ & $\begin{array}{l}\text { Not Supported } \\
\text { the independent variables (Performance } \\
\text { Expectancy, Effort Expectancy, Social } \\
\text { Influence) and BI }\end{array}$ \\
\hline $\mathrm{H}_{10}$ & $\begin{array}{l}\text { Experience moderate the relationship } \\
\text { between the independent variables (Effort } \\
\text { Expectancy, Social Influence) and BI }\end{array}$ & Not Supported \\
\hline
\end{tabular}

Table 15 summarizes the SEM analysis of the effect of research variables on Behavioral Intension. A positive significant impact of Effort Expectancy on Perceived Convenience has been observed, as the estimate is 0.776 and p-value is 0.000 , also, R-square is 0.503 which means that $50.3 \%$ of the variation of the Perceived Convenience can be 
explained by Perceived Convenience. On the other hand, there is a positive significant impact of Perceived Convenience on Performance Expectancy as the estimate is 0.811 and p-value is 0.000 , also, R-square is 0.607 which means that $60.7 \%$ of the variation of the Perceived Convenience can be explained by Performance Expectancy. Furthermore, there is a positive significant impact of Effort Expectancy, Facilitating Conditions, and Trust on Behavioral Intension as the estimates are $0.592,1.083$ and 0.368 and $p$-values are less than 0.05 , also, R-square is 0.405 which means that $40.5 \%$ of the variation of the independent variables can be explained by Behavioral Intension.

Table 15: SEM Analysis of Research Variables on Behavioral Intension

\begin{tabular}{|c|c|c|c|c|c|}
\hline & & & Estimate & $\mathrm{P}$ & $\begin{array}{c}\text { R- } \\
\text { square }\end{array}$ \\
\hline Perceived Convenience & $<---$ & Effort Expectancy & .776 & $* * *$ & .503 \\
\hline $\begin{array}{l}\text { Performance } \\
\text { Expectancy }\end{array}$ & $<---$ & Perceived Convenience & .811 & $* * *$ & .607 \\
\hline Behavioral Intension & $<---$ & $\begin{array}{l}\text { Performance } \\
\text { Expectancy }\end{array}$ & .139 & .442 & \multirow{9}{*}{.405} \\
\hline Behavioral Intension & $<--$ & Perceived Convenience & .341 & .205 & \\
\hline Behavioral Intension & $<---$ & Effort Expectancy & .592 & .018 & \\
\hline Behavioral Intension & $<---$ & Social Influence & -.014 & .917 & \\
\hline Behavioral Intension & $<---$ & Facilitating Conditions & 1.083 & $* * *$ & \\
\hline Behavioral Intension & $<--$ & Trust & .368 & .022 & \\
\hline Behavioral Intension & $<---$ & Age & -.007 & .946 & \\
\hline Behavioral Intension & $<---$ & Gender & -.148 & .233 & \\
\hline Behavioral Intension & $<--$ & Experience & .206 & .237 & \\
\hline
\end{tabular}

The model fit indices; $\mathrm{CMIN} / \mathrm{DF}=2.165, \mathrm{GFI}=0.888, \mathrm{CFI}=0.921, \mathrm{AGFI}=$ 0.831 , and RMSEA $=0.072$ are all within their acceptable levels. The SEM model conducted for the effect of research variables on Behavioral Intension is illustrated in Figure 3. 


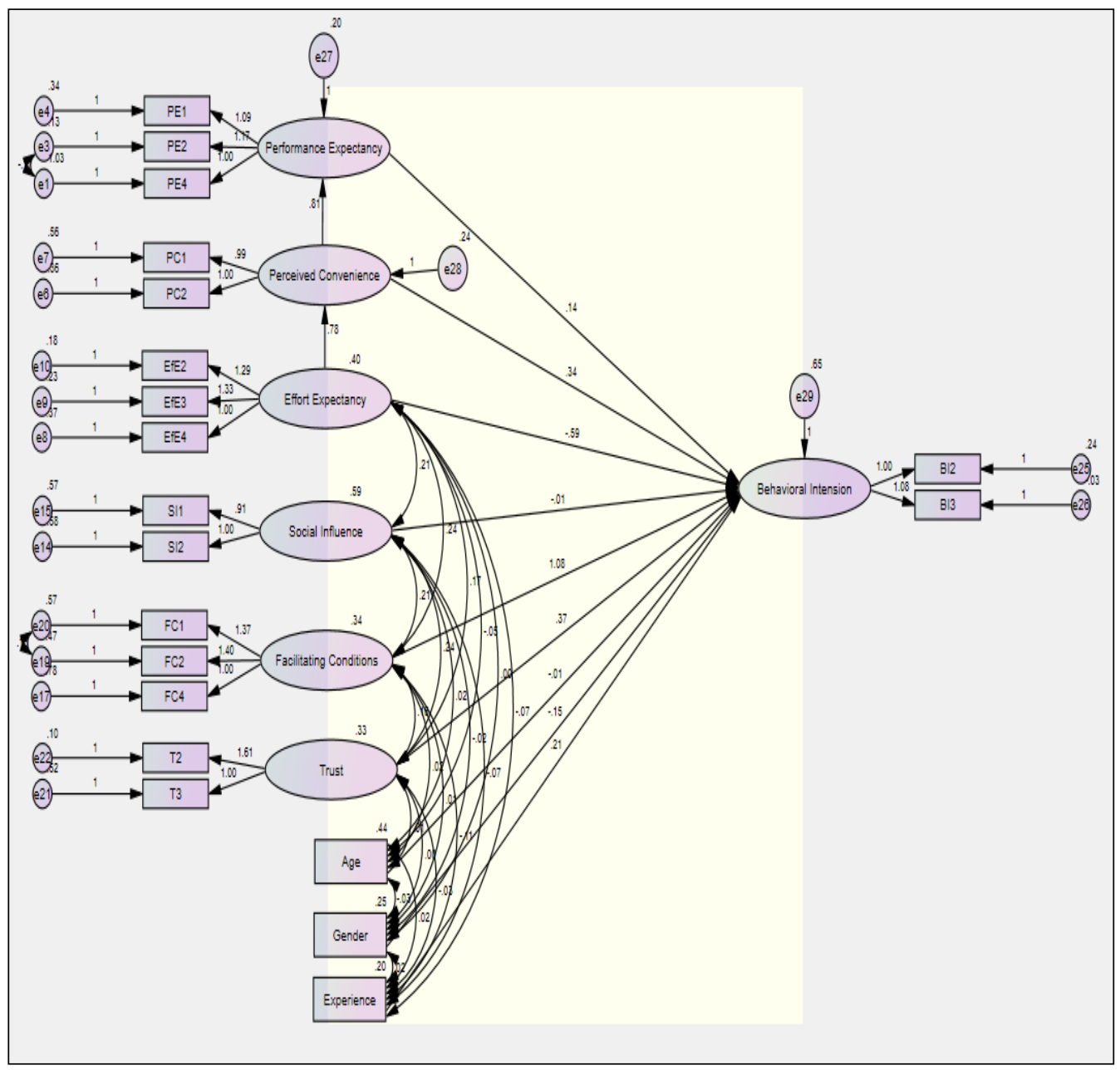

Figure 3: SEM for Research Variables on Behavioral Intension

\section{5- Discussion}

This study developed a modified TAM model, to help identify the factors that aid users accept PC applications at work setting, using Mobile Business Intelligence (MBI) as an initial application of pervasive computing in work environment in Egypt. A review of extant literature indicated that past studies have largely neglected the Unified Theory of Acceptance and Use of Technology (UTAUT) model as it was rarely used in the previous studies which investigated the acceptance of pervasive computing applications. Therefore, the current study attempted to fill this gap by developing and testing an acceptance model for pervasive computing based on UTAUT. Also two variables were added to the proposed model namely; Perceived Convenience and Trust in order to 
predict user acceptance of pervasive computing applications based on users' perception of Performance Expectancy (PE), Effort Expectancy, Social Influence (SI), Facilitating Conditions (FC), Perceived Convenience (PC) and Trust. As well as some moderating variables such as age, gender and work experience.

The study's first hypothesis was examining the positive influence of Performance Expectancy on Behavioral intention. Based on the study results, there has been no significant effect of Performance Expectancy on Behavioral intention, given that the estimate, 0.27 , is greater than the P-value of 0.05 . Therefore, the first hypothesis is not supported. These results however negated Venkatesh et al., 2003 and Al-Gahtani et al., 2007, where The Performance Expectancy had a stronger effect on intension to use in the UTAUT. According to (Yoon \& Kim, 2007) Perceived Usefulness also had a positive significant effect on Behavioral intention.

The users of pervasive computing is divided into two groups: experienced group and non-experienced group. The PU had a positive correlation with intension to use (Martínez-Torres et al., 2015). Their results showed that perceived usefulness made up by previous experience may anticipate intention to use better than that formed by second-hand experience.

A second hypothesis was proposed to examine the relationship between Effort Expectancy and Behavioral intention. According to the study results, the EE had a significant positive effect on Behavioral intention because the estimate is 1.762 and P-value is .010. Therefore, the second hypothesis is fully supported. According to the UTAUT, the EE had a significant effect on Behavioral intention. On the other hand, The EE had insignificant effect on Behavioral intention according to Al-Gahtani et al., 2007.

The Perceived Ease of use matches the PE in UTAUT (Venkatesh et al., 2003). According to (Yoon \& Kim, 2007), the PEOU was considered as a main determinant of intension to use wireless LAN. Their results showed that the PEOU had a positive effect on intension to use. According to (Martínez-Torres et al., 2015), the user of pervasive computing services were divided into two groups: experienced and inexperienced, where it 
was found that there were no significant effects on the intension to use with the inexperienced group.

The third hypothesis was proposed to examine the relationship between Social Influence and Behavioral intention to use. According to this study, the SI has a compelling positive effect on Behavioral intention to use because the estimate is .855 and P-value is .008. In UTAUT, the SI is a determinant of intension to use. Not only did it have positive effect on intension to use computers (Al-Gahtani et al., 2007), but also the SI was considered as an important determinant to intension to use (Connelly, 2007).

The perception of socialness had a positive correlation with perceived usefulness in both experienced and in-experienced groups (MartínezTorres et al., 2015). According to their model (Martínez-Torres et al., 2015), there was no relationship between perception of socialness and intension to use. The social effect acted as a determinant to user acceptance (Bargshady et al., 2015). It also has positive influence on technology acceptance behavior of users.

As for the fourth hypothesis, the influence of Facilitating Conditions on Behavioral intention was examined. The study results indicated that the FC has a significant effect on Behavioral intention because the estimate is .525 and P-value is 0.000 . According to the UTAUT, the FC had no significant effect on intension to use due to the seized effect by the Effort Expectancy. These findings are contrary to the results of this study. The organization climate is an important determinant to user acceptance (Bargshady et al., 2015) as it had the strongest effect on user acceptance.

The effect of Effort Expectancy on Perceived Convenience was validated in the fifth hypothesis. Effort Expectancy was found to have a significant positive effect on perceived Convenience because the estimate is .998 and P-value is 0.000 . Moreover, the R Square is .765, which means that $76.5 \%$ of the variation of the perceived convenience can be explained by the independent variable EE. According to (Yoon \& Kim, 2007) and (Chang et al, 2012), the EE had a positive significant effect on the Perceived Convenience. So, the results of this study were consistent with (Yoon \& Kim, 2007) and (Chang et al, 2012). 
In the sixth hypothesis, perceived convenience was proposed to have a significant impact on performance expectancy. The study results showed that perceived convenience has a significant positive effect on the PE as the estimate is .977 and P-value is 0.000 . Given that the R Square is .675, this means that $67.5 \%$ of the variation of the Performance Expectancy can be explained by the independent variable Perceived Convenience. These results are consistant with (Yoon \& Kim, 2007) and (Chang et al, 2012).

The seventh hypothesis was proposed to examine the effect of Perceived Convenience on Behavioral intention. This paper indicated that Perceived Convenience does not have a significant effect on Behavioral intention, as the estimate is .940 and P-value is .050. The results of (Yoon \& Kim, 2007) also state that perceived convenience does not have a direct impact on an individual's technology acceptance in using the wireless LAN. But it has indirect effect on behavioral intention through Perceived usefulness Expectancy. These findings are consistent with the results of this study.

Finally, the eighth hypothesis validated the effect of Trust on Behavioral intention to use. It was found that Trust has a significant positive effect on Behavioral intention since the estimate is .537and P-value is .006. The trust was considered as an important determinant to intension to use by (Kaasinen, 2005), (Min et al., 2008), (Connelly, 2007) and (Brockmann et al., 2012). According to results of (Septiani et al., 2017), the Trust had a non-significant effect on intension to use.

As for the moderating variables, work experience, age and gender were found insignificant in their relationships with performance expectancy, effort expectancy, social influence and behavioral intension.

\section{6- Research implications}

This research has both theoretical (academic) and managerial (practical) implications. As far as academic implications are concerned, this research is unique in the field of the acceptance of pervasive computing applications such as Mobile Business Intelligence application at work settings. Not only has this study has made a significant contribution to accumulative knowledge in this field but it also offers a number of 
implications for the wider body of knowledge. First of all, this research validates a proposed model which included the extended Unified Theory of Acceptance and Use of Technology (UTAUT) model along with the Trust and Perceived Convenience variables to investigate behavioral intention to use pervasive computing applications in Egypt. The findings of the research confirm the findings of other researchers in the field. This research also contributes to theory by examining the phenomenon under investigation in the context of Egyptian work setting. Despite the number of studies conducted to investigate Acceptance Model (TAM) as a theoretical basis for the investigation the acceptability, determinants of pervasive computing applications in developing countries remains limited, the research findings presented here affirm both similarities and dissimilarities between the aspects applied in Egyptian organizations and a few other aspects applied in the literature.

According to the importance of the acceptance determinants of pervasive computing applications in developing countries, governmental agencies, non-governmental organizations (NGO's) and other institutions (in both Egypt and other developing countries) will gain a much better understanding of the various factors that affect the acceptance of pervasive computing applications such as Mobile Business Intelligence application at work settings. This information will be critical when it comes to planning and direction the future policies, plans and strategies of these institutions and agencies.

\section{7- Conclusion and Future Research}

This paper added to the accumulative knowledge in the field by proposing and testing a modified technology acceptance model for pervasive computing applications. An organized examination of the literature related to the UTUAT model constructs was discussed in order to establish a clear understanding regarding technology acceptance model for pervasive computing applications in Egypt. Perceived Convenience and Trust were added the UTUAT model to applicable in a new trend of pervasive computing applications.

As for the factors affecting individuals' acceptance of MBI in Egypt, the results of this study showed that the Effort Expectancy, Performance Expectancy, Social Influence, Trust and Perceived Convenience, 
Facilitating Conditions had a compelling significant effect on Behavioral Intension to use. Perceived Convenience also had a positive significant impact on Performance Expectancy. $28.9 \%$ of the variation of Performance Expectancy can be explained by the Perceived Convenience. $17.9 \%$ of the variation of the Perceived Convenience can be explained by the independent variable Effort Expectancy. The research model' variables explain $46.7 \%$ of the variation in Behavioral Intension.

The paper further adds to the exceptionally narrow number of empirical studies that have been made to investigate the extended Unified Theory of Acceptance and Use of Technology (UTAUT) model. On the basis of this research, researchers and scholars in this field can have a more distinct view in order to set their attitude towards appropriate future research studies which in turn will contribute to the related accumulated knowledge in the field. Therefore, the paper has generated relevant insights on the impact of Behavioral Intension to use, future research can, therefore focus on actual use rather than intention of usage. Also, the sample utilized in this study is limited to work environment which minimized the generalizability of the findings to other settings.

For the purpose of future research, the proposed model could be tested in new contexts like education, marketing, banking and health. Similar research can be conducted in other developing countries to further distinguish the multitudinous similarities and differences correlated to the factors affecting the acceptance of pervasive computing applications such as Mobile Business Intelligence application at work settings. Also it would be interesting to examine these relationship patterns within different companies around the world in order to further broaden our sample. Despite extending the theoretical and empirical work on the multidimensional nature of the technology acceptance model, this study only considers 3 moderating factors, Age, Gender, and Work experience. Future research can, therefore, consider other dimensions. Cross sectional data analysis was used in this research, in the future proposed model, longitudinal data could be utilized. 


\section{References}

Abdullah, F., \& Ward, R. (2016). Developing a General Extended Technology Acceptance Model for E-Learning (GETAMEL) by Analysing Commonly Used External Factors, Computers in Human Behaviour, (56), 238-256.

Abowd, g. D., \& mynatt, e. D. (2000). Charting past, present, and future research in ubiquitous computing. Acm transactions on computer-human interaction (tochi), (7), 29-58.

Al-gahtani, s. S.; hubona, g. S., \& wang, j. (2007). Information technology (it) in saudi arabia: culture and the acceptance and use of it. Information \& management, (44), 681-691.

Alharbi, s. (2017). An extended utaut model for understanding of the effect of trust on users' acceptance of cloud computing. International journal of computer applications in technology, 56, 65-76.

Bargshady, g.; pourmahdi, k.; khodakarami, p.; khodadadi, t., \& alipanah, f. (2015). The effective factors on user acceptance in mobile business intelligence. Jurnal teknologi (sciences \& engineering), (72), 49-54.

Binyamin, S. (2019). Using the Technoloy Acceptance Model to Measure the Effectd of Usibility Attitudes and Demographic Characterstics on Student use of Learning Manegement Systems in Saudi Higher Education, Unpublished PhD thesis, Edinburah Napier University, UK.

Björk, s.; holopainen, j.; ljungstrand, p., \& åkesson, k. -p. (2002). Designing ubiquitous computing games-a report from a workshop exploring ubiquitous computing entertainment. Personal and ubiquitous computing, (6), 443-458.

Botta, a.; de donato, w.; persico, v., \& pescapé, a. (2016). Integration of cloud computing and internet of things: a survey. Future generation computer systems, (56), 684-700.

Brockmann, t.; stieglitz, s.; kmieciak, j., \& diederich, s. (2012).User acceptance of mobile business intelligence services. Network- 
based information systems (nbis), 2012 15th international conference on, Ieee, 861-866.

Brown, l. G. (1990). Convenience in services marketing. Journal of services marketing, (4), 53-59.

Chang, c.-c.; yan, c.-f., \& tseng, j.-s. (2012). Perceived convenience in an extended technology acceptance model: mobile technology and english learning for college students. Australasian journal of educational technology, (28).

Connelly, k. (2007). On developing a technology acceptance model for pervasive computing. 9th international conference on ubiquitous computing (ubicomp)-workshop of ubiquitous system evaluation (use), springer, innsbruck, austria,. Citeseer, 520.

Davis, f. D. (1989). Perceived usefulness, perceived ease of use, and user acceptance of information technology. Mis quarterly, 319-340.

Fano, a., \& gershman, a. (2002). The future of business services in the age of ubiquitous computing. Communications of the acm, 45, 83-87.

Garfield, m. J. (2005). Acceptance of ubiquitous computing. Information systems management, 22, 24-31.

Ghalandari, k. (2012). The effect of performance expectancy, effort expectancy, social influence and facilitating conditions on acceptance of e-banking services in iran: the moderating role of age and gender. Middle-east journal of scientific research, (12), 801-807.

Hair jr, j. F.; hult, g. T.; ringle, c., \& sarstedt, m. (2016). A primer on partial least squares structural equation modeling (pls-sem), sage publications.

Hu, x.; li, w., \& hu, q. (2008). Are mobile payment and banking the killer apps for mobile commerce? Hawaii international conference on system sciences, proceedings of the 41st annual,. Ieee, 84-84. 
Kaasinen, e. (2005). User acceptance of mobile services: value, ease of use, trust and ease of adoption. Citeseer.

Kheiravar, S. (2018). Exploring the Acceptance of Ubiquitus computingbased Inormation Services in Brick and Morter Retail Envirnment- An Integration of UTAUT2 and Media System Dependence Theory, Unpublished PhD thesis, Technischen University, Hamburg, Germany.

Kim, j., \& chung, k.-y. (2014). Ontology-based healthcare context information model to implement ubiquitous environment. Multimedia tools and applications, (71), 873-888.

Koul, S., \& Eydgahi, A. (2018). Utilizing Technology AcceptNCE Model (TAM) for Driverless Car Technology Adoption, Journal of Technology Management \& Innovation, 13-4.

Kurkovsky, s., \& harihar, k. (2006). Using ubiquitous computing in interactive mobile marketing. Personal and ubiquitous computing, (10), 227-240.

Lee, h. J., \& leem, c. S. (2005). A study on value chain in a ubiquitous computing environment. International conference on computational science and its applications,. Springer, 113-121.

Lyytinen, k., \& yoo, y. (2002). Ubiquitous computing. Communications of the acm, (45), 63-96.

Martínez-torres, m.; díaz-fernández, m.; toral, s., \& barrero, f. (2015). The moderating role of prior experience in technological acceptance models for ubiquitous computing services in urban environments. Technological forecasting and social change, (91), 146-160.

Min, q.; ji, s., \& qu, g. (2008). Mobile commerce user acceptance study in china: a revised utaut model. Tsinghua science and technology, (13), 257-264. 
Mohd, F.; Ahmed, F., \&Sudin, S. (2011). Extending the Technology Acceptance Model to Account for Social Infleunce, Trust and Integration for Pervasive ComputingEnviornment: A Case Study in University Industry, American Journal of Economics and Business Administratuion, 3-3-552-559.

Riad, M.; Jaradat, M., \& Zia, S. (2013). Applying the Technology Acceptance Modelto the Introductionof Mobile Health care Information Systems, International Journal of Behavioural and Healthcare Research, 4-2.

Septiani, r.; handayani, p. W., \& azzahro, f. (2017). Factors that affecting behavioral intention in online transportation service: case study of go-jek. Procedia computer science, (124), 504-512.

Seuwou, P.; Banissi, E., \&Ubakanma, G. (2017). User Acceptance of Information Technology: A Critical Review of Technology Acceptance Models and the Decision to Invest in Information Security, International Conference on Global Security, Safety and Sustainability (ICGSS).

Siewiorek, d. P. (2002). New frontiers of application design. Communications of the acm, (45), 79-82.

Tavakol, m., \& dennick, r. (2011). Making sense of cronbach's alpha. International journal of medical education, (2), 53.

Venkatesh, v., \& bala, h. (2008). Technology acceptance model 3 and a research agenda on interventions. Decision sciences, (39), 273315.

Venkatesh, V., \& davis, f. D. (2000). A theoretical extension of the technology acceptance model: four longitudinal field studies. Management science, (46), 186-204.

Venkatesh, v.; morris, m. G.; davis, g. B., \& davis, f. D. (2003). User acceptance of information technology: toward a unified view. Mis quarterly, 425-478.

Weiser, m. (1991). The computer for the 21st century. Scientific american, 265, 94-104. 
Wu, y.-l.; tao, y.-h., \& yang, p.-c. (2007). Using utaut to explore the behavior of $3 \mathrm{~g}$ mobile communication users. Industrial engineering and engineering management, 2007 ieee international conference on,. Ieee, 199-203.

Yahya, s.; ahmad, e. A., \& jalil, k. A. (2010). The definition and characteristics of ubiquitous learning: a discussion. International journal of education and development using information and communication technology, 6, 1.

Yoon, c., \& kim, s. (2007). Convenience and tam in a ubiquitous computing environment: the case of wireless lan. Electronic commerce research and applications, (6), 102-112.

Zhou, t.; lu, y., \& wang, b. (2010). Integrating ttf and UTAUT to explain mobile banking user adoption. Computers in human behavior, (26), 760-767. 
APPENDIX

Questionnaire items

\begin{tabular}{|c|c|c|}
\hline \multicolumn{3}{|c|}{ Section 1: Demographic Data } \\
\hline moderator & Question & $\begin{array}{l}\text { Question } \\
\text { type }\end{array}$ \\
\hline Age & Please state your age. & $\begin{array}{l}\text { A closed- } \\
\text { ended } \\
\text { question }\end{array}$ \\
\hline gender & Please state your gender. & $\begin{array}{l}\text { A closed- } \\
\text { ended } \\
\text { question }\end{array}$ \\
\hline Experience & $\begin{array}{l}\text { Do you have experience in using MBI } \\
\text { applications? }\end{array}$ & $\begin{array}{l}\text { A closed- } \\
\text { ended } \\
\text { question }\end{array}$ \\
\hline \multicolumn{3}{|c|}{ Section two: study variables } \\
\hline construct & question & $\begin{array}{l}\text { Question } \\
\text { type }\end{array}$ \\
\hline \multirow{4}{*}{$\begin{array}{l}\text { Performance } \\
\text { expectancy }\end{array}$} & 1. I would find the MBI useful in my job. & \multirow{4}{*}{$\begin{array}{l}\text { 5-point Likert } \\
\text { scale }\end{array}$} \\
\hline & $\begin{array}{l}\text { 2. Using the MBI enables me to accomplish tasks } \\
\text { more quickly. }\end{array}$ & \\
\hline & 3. Using the MBI increases my productivity & \\
\hline & $\begin{array}{l}\text { 4. If I use the MBI, I will increase my chances of } \\
\text { getting a raise. }\end{array}$ & \\
\hline \multirow{4}{*}{$\begin{array}{c}\text { Effort } \\
\text { Expectancy }\end{array}$} & $\begin{array}{l}\text { 5. My interaction with the MBI applications would } \\
\text { be clear and understandable. }\end{array}$ & \multirow{4}{*}{$\begin{array}{l}\text { 5-point Likert } \\
\text { scale }\end{array}$} \\
\hline & $\begin{array}{l}\text { 6. It would be easy for me to become skillful at } \\
\text { using the MBI applications. }\end{array}$ & \\
\hline & 7. I would find the MBI applications easy to use. & \\
\hline & $\begin{array}{l}\text { 8. Learning to operate the MBI applications is easy } \\
\text { for me }\end{array}$ & \\
\hline \multirow{4}{*}{$\begin{array}{l}\text { Social } \\
\text { Influence }\end{array}$} & $\begin{array}{l}\text { 9. People who are important to me think that I } \\
\text { should use the MBI applications. }\end{array}$ & \multirow{4}{*}{$\begin{array}{l}\text { 5-point Likert } \\
\text { scale }\end{array}$} \\
\hline & $\begin{array}{l}\text { 10. The senior management of this business has } \\
\text { been helpful in the use of the MBI } \\
\text { applications. }\end{array}$ & \\
\hline & $\begin{array}{l}\text { 11. In general, the organization has supported the } \\
\text { use of the MBI applications. }\end{array}$ & \\
\hline & $\begin{array}{l}\text { 12. If the MBI is popular in the social media of the } \\
\text { organization, this would make me excited. }\end{array}$ & \\
\hline \multirow{2}{*}{$\begin{array}{l}\text { Facilitating } \\
\text { Conditions }\end{array}$} & $\begin{array}{l}\text { 13. I have the resources necessary to use the MBI } \\
\text { applications. }\end{array}$ & \multirow{2}{*}{$\begin{array}{l}\text { 5-point Likert } \\
\text { scale }\end{array}$} \\
\hline & $\begin{array}{l}\text { 14. I have the knowledge necessary to use the MBI } \\
\text { applications. }\end{array}$ & \\
\hline
\end{tabular}




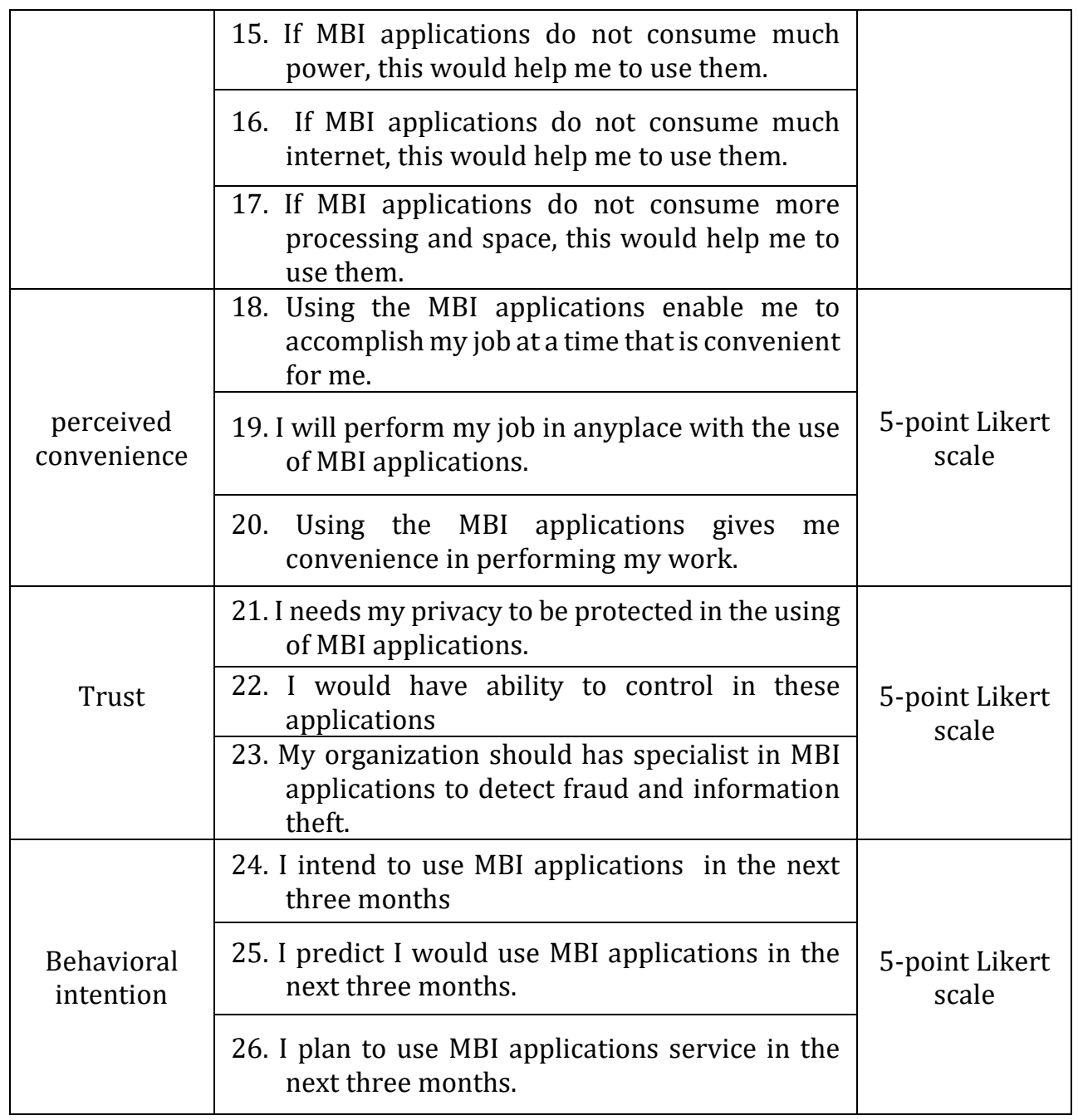


نموذج قبول التكنولوجيا للحوسبة المنتشرة : تطبيقات ذكاء الأعمال المتنقلة في مصر

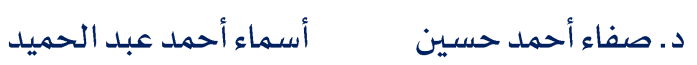

\section{ملخص البحث باللغة العربية}

الحوسـبة المنتشــرة هي نموذج جديد في تكنولوجيا المعلومات. على مدى العقدين الماضـيين، تم تطوير العديد من تطبيقات

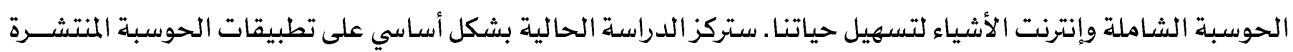
في بيئسة العمـل والتحقق من صـحسة النموذج المقترح تجريبيـا. تم اختيـار تطبيق كتكنولوجيا للمرحلة الأولية للحوسبة المنتشرة.

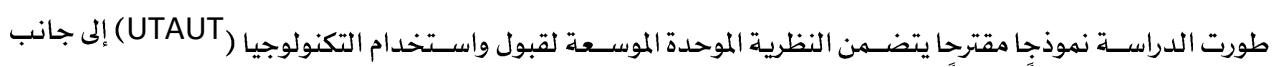

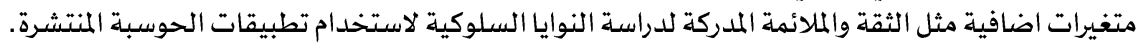

باستخدام قوائم الاستبيان تم جمع البيانات من 277 موظف في بعض الشـركات في مصــــ تم استخدام الارتباط والانحدار

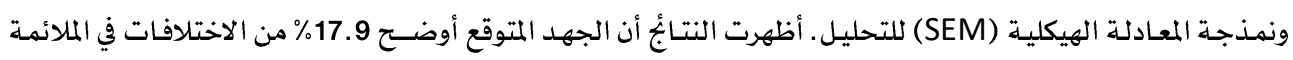

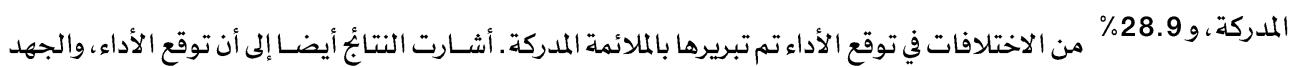

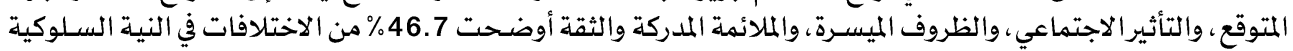
لاستخدام تطبيقات الحوسبة المنتشرة. الدراسة ستقدم فوائد عظيمة لرواد الأعمال وصناع السياسات والممارسين والباحثين والمعلمين من خلال توفيرؤية أوضح

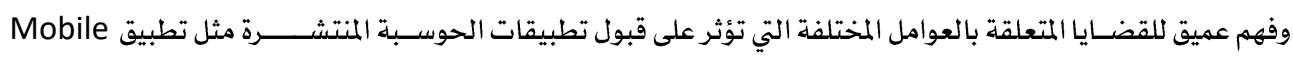
Business Intelligence الكلمات الدالة: الحوسبة الشاملة، MBM ،UTAUT، ذكاء الأعمال المتنقلة MBM، مصر.

\section{Suggested Citation according to APA Style}

Hussein, S. A. and Abdelhamid, A. A. (2021). Technology Acceptance Model for Pervasive Computing: Mobile Business Intelligence Applications in Egypt. Journal of Alexandria University for Administrative Sciences, Faculty of commerce, Alexandria University 58(2), 291 - 326. 